\title{
An experimental study on the influence of the bloom-forming alga Gonyostomum semen (Raphidophyceae) on cladoceran species Daphnia magna
}

\author{
Wojciech Pęczuła ${ }^{1, *}$, Magdalena Toporowska ${ }^{1}$, Barbara Pawlik-Skowrońska ${ }^{1}$ and Judita Koreiviene ${ }^{2}$ \\ ${ }^{1}$ Department of Hydrobiology, University of Life Sciences in Lublin, Lublin, Poland \\ ${ }^{2}$ Institute of Botany, Nature Research Center, Vilnius, Lithuania
}

\begin{abstract}
The effect of the unicellular, bloom-forming alga Gonyostomum semen (Raphidiophyceae) on the survival rate and body size of Daphnia magna was tested under experimental laboratory conditions. Using samples from four humic lakes with a long history of Gonyostomum blooms, we exposed D. magna for $72 \mathrm{~h}$ to various Gonyostomum treatments which included homogenized biomass (frozen and fresh), live cell populations as well as lake water separated from the concentrated biomass of live cells. Filtered lake water and the chlorophycean alga Stichococcus bacillaris population (homogenized biomass or live cells) we used as controls. Our study revealed that (1) frozen homogenized G. semen biomass in the concentrations typical for blooms was not harmful for Daphnia and appeared to have a nutritive effect because it supported its growth; however, Daphnia mortality occurred after exposure to fresh and highly concentrated cell homogenate containing high amount of mucilage; (2) it is unlikely that living Gonyostomum cells excrete extracellular substances harmful for Daphnia; however, dense live Gonyostomum population that formed mucilaginous aggregates immobilized Daphnia and increased its mortality. The results suggest that various interactions between $G$. semen and D. magna take place and may play an essential role in natural freshwater ecosystems.
\end{abstract}

Keywords: algal blooms / mucilage / crustaceans / toxicity

Résumé - Une étude expérimentale de I'influence de l'algue formant des efflorescences Gonyostomum semen (Raphidophyceae) sur l'espèce de cladocère Daphnia magna. L'effet de l'algue unicellulaire, formant des efflorescences, Gonyostomum semen (Raphidiophyceae) sur le taux de survie et la taille corporelle de Daphnia magna a été testé dans des conditions expérimentales de laboratoire. En utilisant des échantillons de quatre lacs humiques avec un long passé d'efflorescences de Gonyostomum, nous avons exposé $D$. magna pendant $72 \mathrm{~h}$ à différents traitements de Gonyostomum qui incluent: la biomasse homogénéisée (congelée et fraîche), des populations de cellules vivantes ainsi que l'eau du lac séparée de la biomasse concentrée de cellules vivantes. L'eau filtrée du lac et une population d'algues chlorophycées Stichococcus bacillaris (biomasse homogénéisée ou cellules vivantes) ont été utilisées comme témoins. Notre étude a révélé que: (1) la biomasse congelée homogénéisée de G. semen dans les concentrations typiques d'efflorescences n'était pas nocif pour Daphnia et semblait avoir un effet nutritif car elle a soutenu sa croissance, cependant, la mortalité de Daphnia a eu lieu après une exposition à un homogénat frais et hautement concentré de cellules contenant une grande quantité de mucilage; (2) il est peu probable que les cellules vivantes de Gonyostomum excrètent des substances extracellulaires nocives pour Daphnia, cependant, une population vivante dense de Gonyostomum vivante qui a formé des agrégats mucilagineux a immobilisé Daphnia et a augmenté sa mortalité. Les résultats suggèrent que diverses interactions entre G. semen et D. magna ont lieu et peuvent jouer un rôle essentiel dans les écosystèmes naturels d'eau douce.

Mots-clés : bloom à Gonyostomum / mucilage / Daphnia magna / toxicité

\footnotetext{
* Corresponding author: wojciech.peczula@up.lublin.pl
} 


\section{Introduction}

Interactions between planktonic algae (including cyanobacteria) and zooplankton have been intensively studied for decades in terms of the regulation of plankton communities by top-down and bottom-up control mechanisms (Agrawal, 1998; Ger et al., 2014). Generally, research is primarily focused on direct trophic interactions covering zooplankton grazing as well as phytoplankton defence strategies (Lampert, 1987; Tillmann, 2004).

Phytoplankton has developed various defence mechanisms against zooplankton grazing pressure. These include, among others, increase of cell size (Yoshida et al., 2004; Kampe et al., 2007), change of cell morphology (Van Donk et al., 1997), motility, which enables active escape (Strom and Buskey, 1993; Buskey, 1997), agglomerating into aggregates (Hessen and Van Donk, 1993), as well as production of various chemical substances for repelling or toxic action towards zooplankton (Wolfe, 2000; Pohnert et al., 2007). Some algae have developed very "active" modes of defence by ejecting threads of mucilage from trichocysts which act as a repellent for grazers. This phenomenon is known in dinoflagellates (like Oxyrrhis marina, Martel and Flynn, 2008) as well as in raphidophytes (like Fibrocapsa japonica, Tillmann and Reckermann, 2002). Some marine raphidophytes are also known to produce toxic compounds, which may be lethal or sublethal for fish, crustaceans or ciliates (Yan et al., 2003; Fu et al., 2004; Okaichi, 2004; Clough and Strom, 2005; Mohamed and Al-Shehri, 2012).

The freshwater raphidophyte group consists of several species (Fott, 1968), from which Gonyostomum semen is the best known and intensively studied over the last decade due to the increase in its abundance and common occurrence in European aquatic ecosystems (Cronberg et al., 1988; Rengefors et al., 2012; Pęczuła, 2013; Karosiene et al., 2014; Hagman et al., 2015). The species was previously considered inedible (Havens, 1989) due to its large dimensions which are above the preferred size range for many filterfeeding zooplankton. In addition, its cells lack a cell wall and contain mucilaginous trichocysts (South and Whittick, 1987) which make them very fragile and results in the cell disintegration under the influence of chemical or physical stimulus. In this case, they eject threads of mucilage from trichocysts which could be a repellent (or possibly toxin) for zooplankton. This mode of action was proposed by Cronberg et al. (1988) to be a defence mechanism against grazers. Nevertheless, recent experimental studies revealed that $G$. semen cells may be grazed by some rotifers (Asplanchna priodonta), cladocerans (Daphnia magna, D. pulicaria, Holopedium gibberum) or copepods (Diaptomus oregonensis, Eudiaptomus gracilis) (Williamson et al., 1996; Lebret et al., 2012; Johansson et al., 2013; Björnerås, 2014). As reported by Hagman et al. (2015), in lakes with high Gonyostomum biomass, bathers often suffered from skin irritation and itching after contact with lake water. This has had social consequences in Scandinavia where several bathing places lost their recreational attractiveness, and the Swedish Environmental Protection Agency recognizes this alga as a noxious species (Angeler and Johnson, 2013). In many papers (Cronberg et al., 1988; Findlay et al., 2005; Figueroa and Rengefors, 2006; Trigal et al., 2011), this species is described as a "noxious" or a "nuisance". Rengefors et al. (2008) reported that G. semen caused cell lysis of small phytoplankton flagellates, what suggests that it can be harmful for other freshwater organisms. Some field studies focused on the impact of $G$. semen blooms on phytoplankton, zooplankton, benthic invertebrates and fish (Trigal et al., 2011; Angeler and Johnson, 2013; Johansson et al., 2013), but there is no evidence that this species may negatively affect zooplankton in a direct way. To fulfill this gap, we designed an experimental study with the aim to test the influence of $G$. semen biomass on zooplankton using D. magna as a model organism.

\section{Materials and methods}

\subsection{Sampling and extraction of Gonyostomum biomasses}

Algal samples were collected in the end of July and the beginning of August 2014 from four humic lakes which have had a long history of G. semen blooms (Pęczuła et al., 2013; Karosiene et al., 2014). Two lakes are located in Eastern Poland (Jelino and Płotycze) and two in Lithuania (Slabada and Natalka). G. semen was a dominating species in phytoplankton of all lakes composing from 91 to $96 \%$ of the total phytoplankton biomass with a low proportion of the other algae, mainly small phytoflagellates (cryptophytes, chlorophytes and euglenophytes). Lake water (18-25 L) was sampled by means of the Ruttner sampler in the central part of each lake: from $0.5 \mathrm{~m}$ in shallow lakes and $3 \mathrm{~m}$ in deeper lakes, i.e. at depths of expected high Gonyostomum abundance (Pęczuła et al., 2013; Karosiene et al., 2014). All samples were kept in the dark and protected against heating during transportation to the laboratory.

The following $G$. semen preparations were made to test their effects on D. magna: (a) G. semen cell homogenates obtained from the four sampled lakes (marked as "H"); (b) water from concentrated live G. semen biomass sampled from the same lakes, after removal of algal cells by filtration (marked as "W"); (c) homogenized fresh G. semen biomass with four- to five-fold higher density compared to the afore mentioned treatments, obtained from Lake Jelino (marked as "FH"); (d) dense biomass of live G. semen cells from Lake Jelino (marked as "L").

Lake water samples were three times gently filtered through a plankton net ( $25 \mu \mathrm{m}$ mesh) to the volume of $1 \mathrm{~L}$ and gently centrifuged $\left(4000 \mathrm{rpm}\right.$ for $10 \mathrm{~min}$ at $\left.20^{\circ} \mathrm{C}\right)$. After centrifugation, the pellets were collected, and the concentrated samples were combined, giving a total of $100 \mathrm{~mL}$ sample from each lake. Gonyostomum cells were live in all concentrated samples, as noted by examination under light microscope. The dense samples were kept frozen at $-20^{\circ} \mathrm{C}$ for 2 or 3 weeks (depending on the lake). On the day of the experiment setup, samples were thawed out and part of the sample was filtered through GF/C Whatman glass fiber filters to be used in the experiment as "W" treatments (filtered water). The rest of the biomass samples $(10 \mathrm{~mL})$ were ultrasonicated (two-times for $5 \mathrm{~min}$ at $50 \mathrm{~W}$ in Sonoplus, Bandelin ultrasonic homogenizer), and after centrifugation $\left(14000 \mathrm{rpm}\right.$ for $10 \mathrm{~min} 20^{\circ} \mathrm{C}$ ) supernatants were collected and used in the tests as " $\mathrm{H}$ " treatments (homogenates). In addition, we collected extra samples from Lake Jelino to 
prepare much higher concentrated homogenates according to the same procedure as above with the exception that extracts were used directly without freezing and thawing ("FH" treatments). For experiments with live cells of Gonyostomum (marked as "L"), the algal samples were collected and concentrated as described before and were kept for three days under light:dark cycle $-14: 10 \mathrm{~h}$, light intensity $10 \mu \mathrm{mol}$ $\mathrm{m}^{-2} \mathrm{~s}^{-1}$, at $20^{\circ} \mathrm{C}$ (to mimic light and temperature conditions in sampled lake).

\subsection{Experimental procedures}

Although D. magna is a crustacean rarely occurring in humic lakes, we decided to use this species as it is the most often tested zooplankter in aquatic toxicology. We used juvenile D. magna hatched from eggs (Daphtoxkit FTM MAGNA) delivered by MicroBioTests Inc. (Belgium). The incubation and bioassays were conducted according to the producer protocols, compatible with OECD Standard Guideline 202 (1996). After $72 \mathrm{~h}$ incubation in standard medium (light $60001 \mathrm{x}$, temperature $20^{\circ} \mathrm{C}$ ) and hatching, daphnids were fed with lyophilized Spirulina. For preparation of the standard medium (ISO 6341, 2012), up to $2 \mathrm{~L}$ of deionized water and following concentrated salts: $\mathrm{NaHCO}_{3}$ $\left(67.75 \mathrm{mg} \mathrm{L}^{-1}\right), \quad \mathrm{CaCl}_{2} \times 2 \mathrm{H}_{2} \mathrm{O} \quad\left(294 \mathrm{mg} \mathrm{L}^{-1}\right), \quad \mathrm{MgSO}_{4} \times 7$ $\mathrm{H}_{2} \mathrm{O}\left(123.25 \mathrm{mg} \mathrm{L}^{-1}\right), \mathrm{KCl}\left(5.75 \mathrm{mg} \mathrm{L}^{-1}\right)$ were used. Then, five individuals were flushed with the medium solution and transferred to $5 \mathrm{~mL}$ experimental chambers. Increasing concentrations of $G$. semen homogenates (expressed as chla: $85-3576 \mathrm{mg} \mathrm{m}^{-3}$, which corresponded to G. semen biomass range of $9-386 \mathrm{~g}$ of fresh weight $[\mathrm{FW}] \mathrm{m}^{-3}$ ) or increasing biomass of live cells (72-773 $\mathrm{g} \mathrm{m}^{-3}$, respectively) were used in three replicate experiments. As controls, we always used filtered (GF/C Whatman) lake water, marked in experiments as " $\mathrm{C}(\mathrm{W})$ ". In the bioassays with $G$. semen extracts ("H") and alive cells ("L"), we used additional controls: (a) a homogenized biomass of the chlorophycean microalga Stichococcus bacillaris, marked as " $\mathrm{C}(\mathrm{Sb})$ " (chl- $a$ : $4202 \mathrm{mg} \mathrm{m}^{-3}$ ), prepared in the same way as that of G. semen; (b) alive cells of $S$. bacillaris $\left(72 \mathrm{~g} \mathrm{FW} \mathrm{m}^{-3}\right)$, respectively. Multiwell plates with $D$. magna and extracts were kept in a growth chamber at $20^{\circ} \mathrm{C}$ in darkness, whereas plates with alive $G$. semen were kept at the light:dark cycle $(14: 10 \mathrm{~h})$, light intensity of $10 \mu \mathrm{mol} \mathrm{m} \mathrm{s}^{-2}$, and $20^{\circ} \mathrm{C}$.

The experiments were carried out for $72 \mathrm{~h}$. Every $24 \mathrm{~h}$ we checked the viability and general condition of Daphnia specimens under a microscope and classified those into "live" or "dead" categories. During $L$ tests in which $G$. semen cells formed mucilaginous aggregations, we classified $D$. magna to three classes: "live swimming", "live entrapped" or "dead entrapped". The test end-point was a death or/and entrapment of the organisms. Data obtained from the bioassays were expressed as the percentage $(\%)$ of the organisms' survival or entrapment compared to the respective controls (in which the survival rate was always $100 \%$ in all experimental variants).

$G$. semen abundance, fresh weight and/or chlorophyll- $a$ concentration (ISO 10260, 1992) were determined before the set-up of the experiments. The abundance and fresh weight were determined using an inverted microscope according to Utermöhl's method (Vollenweider, 1969). As there is no generally accepted formula for Gonyostomum biovolume calculation in the published data, we have chosen a prolate spheroid as a geometric model (Hillebrand et al., 1999). We recalculated the biovolume to fresh weight with an assumption that the density of algal cells equals $1 \mathrm{~g} \mathrm{~cm}^{-3}$. At the end of the experiments, we measured also the body length of the survived D. magna. Prior to the measurements, Daphnia specimens were fixed in formaldehyde.

\subsection{Statistical analysis}

In order to determine the significance of differences in daphnids length between controls and various treatments, a nonparametric Mann-Whitney $U$ test was performed according to the fact that there were significant difference between the variances in population analysed (Levene's test, mean, $P<0.01)$. In the case of two series of data ( $H$ tests in lakes Natalka and Slabada: treatments against "CSb" control), where variances were homogenous, a Student $t$-test was used. Pearson correlation was used to determine the relationship between the amount of $G$. semen homogenate added and daphnids body length. The test of Shapiro-Wilk was performed to verify the normal distribution of the analysed data. All analyses were carried out using XLSTAT add-in for MS Excel (Addinsoft).

\section{Results}

\subsection{The effect of homogenized G. semen biomass on Daphnia survival rate}

Generally, addition of increased amounts of homogenized G. semen biomass (frozen and thawed out, "H" treatments) in the range of $84-1530 \mathrm{mg} \mathrm{m}^{-3}$ (corresponding to 9-161 $\mathrm{g}$ $\mathrm{FW} \mathrm{m}^{-3}$ ) did not affect Daphnia survival rate (Fig. 1). However, in the experimental variant with the most concentrated $G$. semen cell homogenate (Lake Jelino; chl$a=3503 \mathrm{mg} \mathrm{m}^{-3}$, biomass $=378 \mathrm{~g} \mathrm{FW} \mathrm{m}^{-3}$ ) the survival rate of daphnids decreased to $60 \%$ after $24 \mathrm{~h}$ and $40 \%$ after $48 \mathrm{~h}$ of exposure in comparison with controls (Fig. 1). Fresh cell homogenate of $G$. semen collected from Lake Jelino ("FH" treatments) with chl- $a$ range: $894-3576 \mathrm{mg} \mathrm{m}^{-3}$ had a distinct negative effect on Daphnia survival (Fig. 2). This negative effect increased with increasing biomass of alga and time of exposure. At lower chl- $a$ concentration (894 and $1778 \mathrm{mg} \mathrm{m}^{-3}$ ), the survival rate averaged $40-70 \%$ after $24 \mathrm{~h}$ and $20-30 \%$ after 48 and $72 \mathrm{~h}$ of exposure. However, the addition of the most concentrated and fresh $G$. semen homogenized biomass (chl- $a$ : $3576 \mathrm{mg} \mathrm{m}^{-3}$ ) caused $100 \%$ Daphnia mortality after $24 \mathrm{~h}$ (Fig. 2). When the water separated by filtration ("W" treatments) from the concentrated G. semen biomass was added to experimental chambers with Daphnia no mortality of the organisms was observed.

\subsection{The effect of homogenized G. semen biomass on Daphnia body length}

The addition of frozen and then thawed out homogenized $G$. semen biomass from all lakes ("H" treatments) considerably influenced daphnids body length measured after $72 \mathrm{~h}$ 

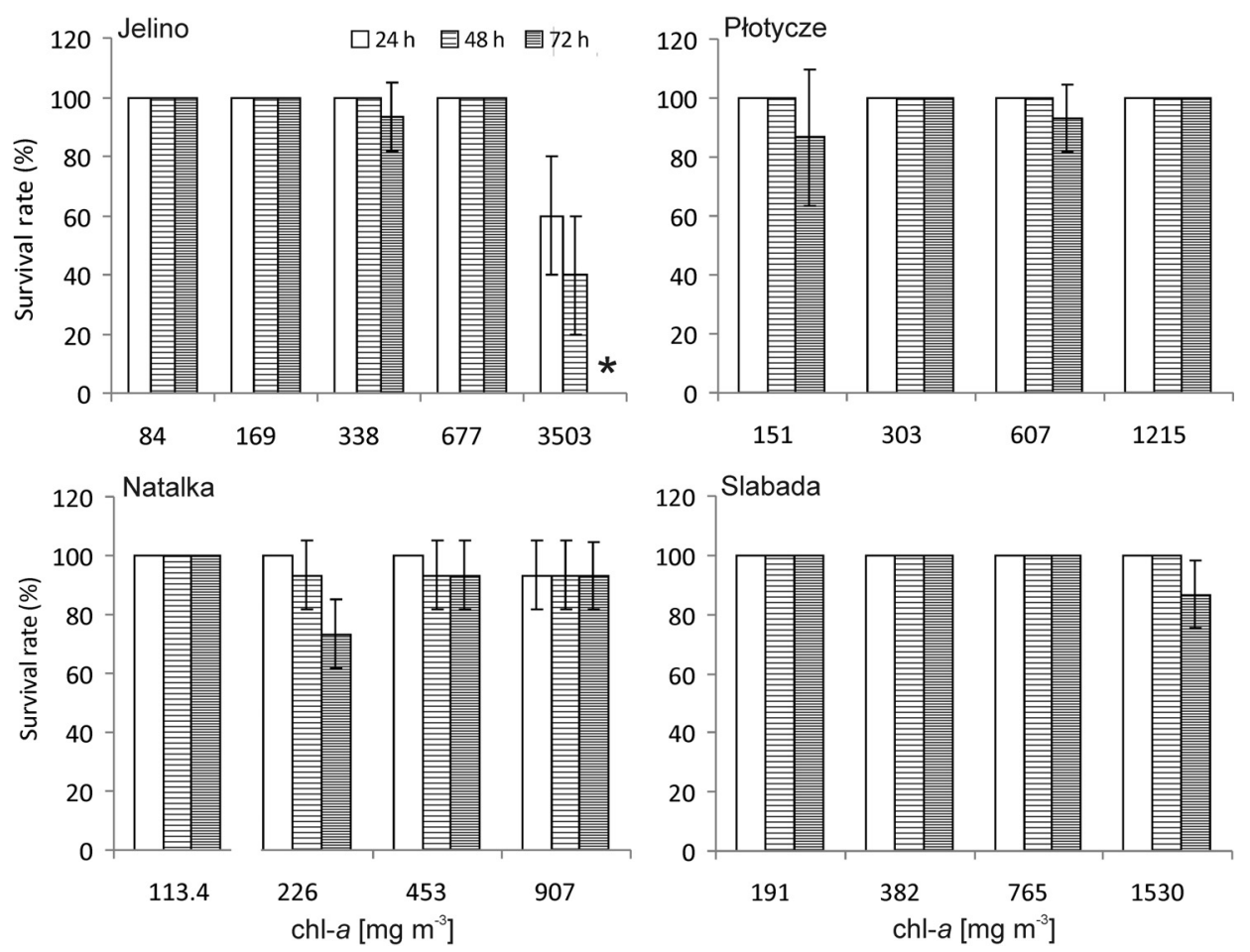

Fig. 1. The survival rate of daphnids' treated by increasing amounts of homogenized biomass of GS expressed as chl- $a$ concentrations. The survival rate in controls was set as $100 \%$.

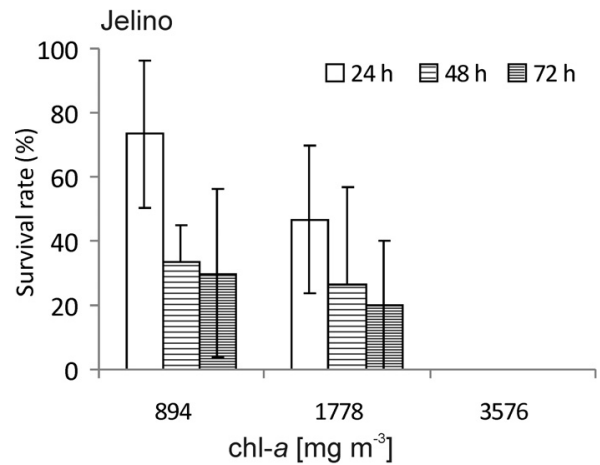

Fig. 2. The survival rate of daphnids' treated by fresh homogenized biomass of GS from lake Jelino. The survival rate in controls was set as $100 \%$.

exposure (Fig. 3). At increasing homogenate concentrations (chl-a: $84-1530 \mathrm{mg} \mathrm{m}^{-3}$ ) body length of Daphnia was always significantly greater compared with filtered water controls $(P<0.01$, Mann-Whitney $U$ test $)$ and in some cases (at chl- $a \geq 453 \mathrm{mg} \mathrm{m}^{-3}$ ) when compared with $S$. bacillaris homogenate controls $(P<0.01$, Mann-Whitney $U$ test or Student's $t$-test). Generally (Fig. 4), Daphnia body lengths positively correlated with the algal homogenate concentration $\left(r^{2}=0.57, P<0.01\right.$, Fig. $\left.4 a\right)$.

When fresh $G$. semen homogenate ("FH" treatments) was used, we also observed the slight increase of daphnids body length after $72 \mathrm{~h}$ exposure (Fig. 5), but it was not statistically significant $(P=0.108-0.231$, Mann-Whitney $U$ test).

\subsection{The effect of live G. semen cells on daphnids survival rate and body length}

The effect of dense live Gonyostomum population on daphnids survival rate was tested with the use of the samples from lake Jelino ("L" treatments) (Fig. 6). The addition of increasing amounts of algal cells had a dose- and timedependent negative effect on daphnids survival rate. Increased Daphnia mortality was observed at two highest G. semen biomass additions ( 386 and $773 \mathrm{~g} \mathrm{FW} \mathrm{m}^{-3}$ ), where the survival rate decreased to $40-60 \%$ of the control after $72 \mathrm{~h}$ of the exposure (Fig. 6a). Simultaneously, we observed that after $24 \mathrm{~h}$ of experiment (Fig 6b) most daphnids (from 40 to $100 \%$, depending on the treatment) were entrapped in mucilaginous macroscopic aggregations of G. semen cells (of a few $\mathrm{mm}$ in a diameter). After increased time ( $72 \mathrm{~h}$ ), all Daphnia specimens were entrapped in the mucilaginous aggregations - live or dead. Only a few free-swimming specimens of Daphnia were found at densities of G. semen cells of 96-193 $\mathrm{g} \mathrm{FW} \mathrm{m}^{-3}$ and any at the two highest densities (Fig. 6c) at the end of the experiment. Neither G. semen ingestion by daphnids nor a presence of algal cells inside Daphnia guts were observed during the experiment. Moreover, we did not observe any positive effect on daphnids' body length during any of the tested quantities of live G. semen cells (Fig. 7).

\section{Discussion}

In the present study, we aimed to evaluate the effect of very high $G$. semen biomass on the survival rate of the common member of freshwater zooplankton D. magna. The analysis of 

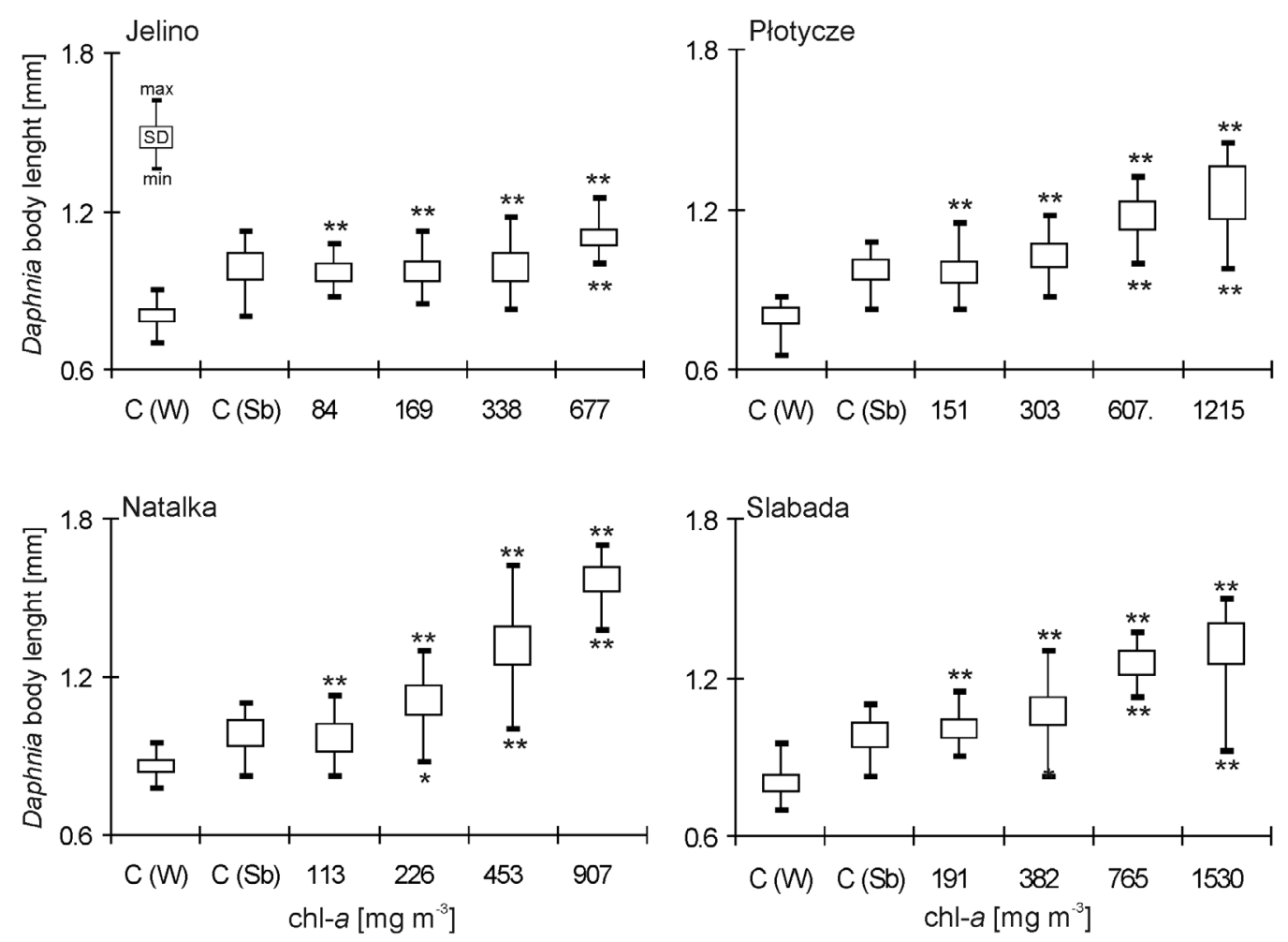

Fig. 3. Body length of Daphnia (DL) exposed for $72 \mathrm{~h}$ to homogenized GS biomasses from various lakes (C(W) - lake water control, C (Sb) homogenized Stichococcus bacillaris biomass control; asterix above bars = significant difference against $\mathrm{C}(\mathrm{W})$ control, asterix below bars $=$ significant difference against $\mathrm{C}(\mathrm{Sb})$ control, $* P<0.05$, ** $P<0.01$, Mann-Whitney test or Student's $t$-test).

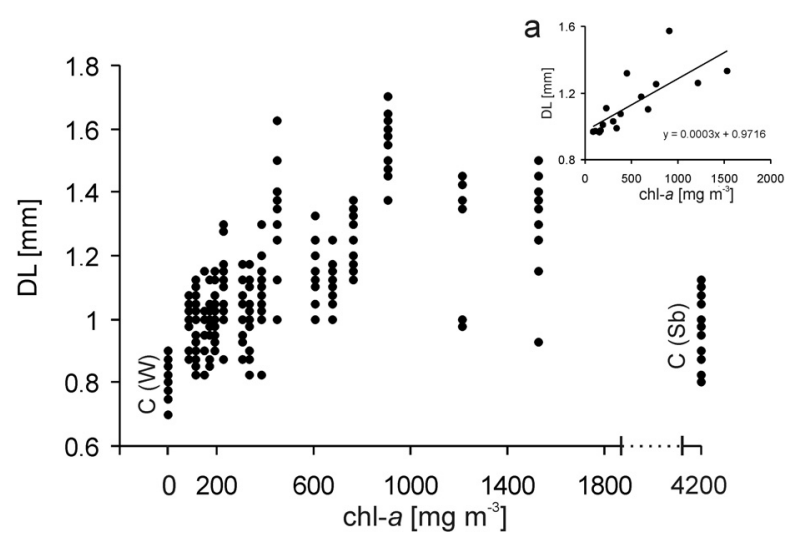

Fig. 4. Daphnids' body length (DL) related to the density of homogenized GS biomass addition; a - relationship between mean body length and chl- $a$ concentrations (C (W) - lakes water control, C (Sb) - homogenized Stichococcus bacillaris biomass control).

the results leads to the conclusion that: (a) G. semen biomass frozen prior to the experiment and then homogenized even in high typical bloom concentrations were not harmful for D. magna. Moreover, it appeared to be nutritive for the crustaceans as it supported their body growth; (b) daphnids' mortality occurred only after addition of very concentrated fresh homogenate (much higher than this occurring during blooms in lakes); (c) it is unlikely that live G. semen exudate or extra-cellular substances were harmful for Daphnia as the filtered water did not affect them; (d) dense live Gonyostomum cells population that formed mucilaginous aggregates immobilized Daphnia physically and increased its mortality.

Harmful action of fresh $G$. semen homogenates was detected at the biomass concentrations considerably exceeding the values found commonly in natural lakes. Reports from Scandinavia and Canada show that during Gonyostomum blooms the alga forms biomass between 1 and $20 \mathrm{~g}$ fresh biomass $\mathrm{m}^{-3}$ (Lepistö et al., 1994; Hongve et al., 1988; Findlay et al., 2005; Angeler et al., 2010; Trigal et al., 2011) and very rarely as high as $45 \mathrm{~g}$ fresh biomass $\mathrm{m}^{-3}$ (Cronberg et al., 1988; Hagman et al., 2015). Nevertheless, G. semen can occasionally be found in extremely high densities. A few studies from countries situated south of Scandinavia reported one order of magnitude higher maximum biomass of the alga which ranged 143-841 $\mathrm{g}$ fresh biomass $\mathrm{m}^{-3}$ (Pithart et al., 1997; Hehmann et al., 2001; Pęczuła et al., 2013; Karosiene et al., 2014) and which more or less correspond to densities used in our experiments. Gonyostomum density, even during blooms, in lakes of non-Scandinavian part of Europe is usually not higher than $50 \mathrm{mg} \mathrm{FW} \mathrm{L}^{-1}$ (Le Cohu et al., 1989; Vetrova and Okhapkin, 1990; Negro et al., 2000; Hutorowicz et al., 2006; Pęczuła, 2013; Karosiene et al., 2014); therefore, the previously noted extremely high and incidental biomass values may be an exception rather than the rule. The results obtained here indicated that the high $G$. semen biomass typical of lakes is generally not toxic for daphinds. The lower survival rates of daphnids observed at extremely high concentrations of fresh homogenate in our experiment may be thus explained by the mechanical trapping and immobilization through the high 


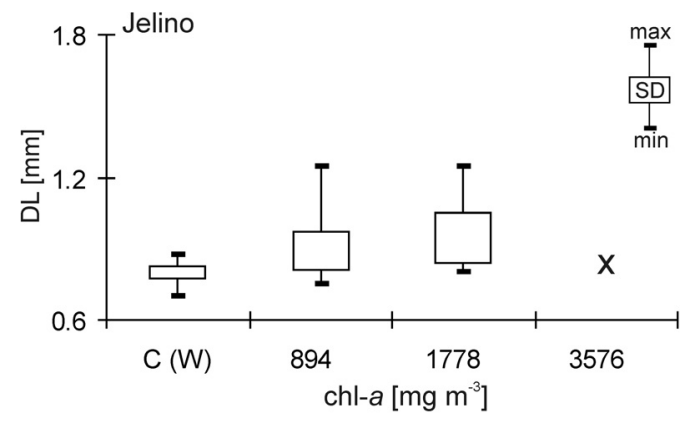

Fig. 5. Daphnids' body length (DL) after 72-h exposure on fresh homogenized biomass of GS from Lake Jelino $(\mathrm{C}(\mathrm{W})$ - lake water control). $\mathrm{x}$ - no live daphnids occurred and their body length was not estimated.
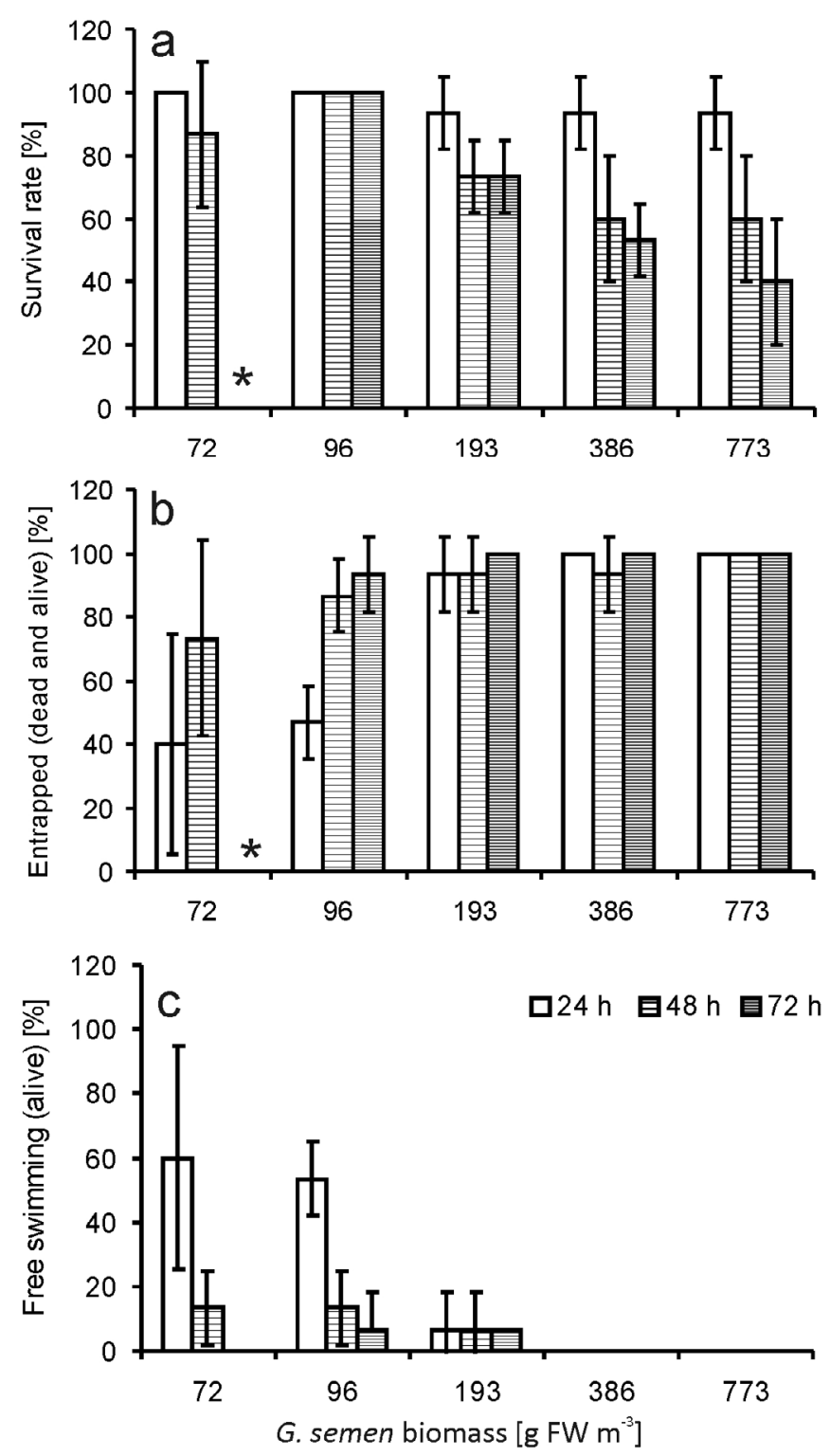

Fig. 6. Daphinds' response to the addition of GS live cells from Lake JEL $(100 \%=$ control $){ }^{*}-72$-h exposure not tested.

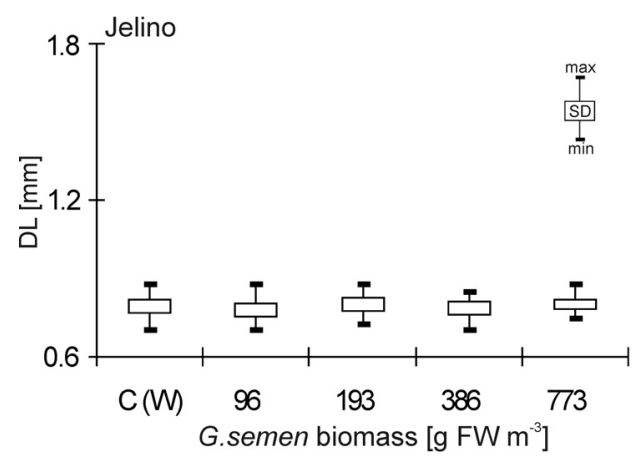

Fig. 7. Daphnids' body length (DL) after 72-h exposure to GS live cells collected from Lake Jelino $(\mathrm{C}(\mathrm{W})$ - lake water control).

mucilage amount released by G. semen biomass. Nevertheless, the fact that the fresh homogenate used had a more negative influence on Daphnia survival rate (in comparison to frozen one) may suggest that $G$. semen cells might contain some intracellular compounds with potentially harmful action which may be unstable and could be reduced by freezing and thawing. Some harmful algal secondary metabolites, e.g. various cyanotoxins (anatoxin-a, microcystins) produced by cyanobacteria, are known to have different stability dependent on various factors like temperature or light (Tsuji et al., 1995; Hardy, 2008). However, our conclusion should be treated with caution as the concentrations of fresh and frozen homogenates in the experiment were not the same, but only to some extent comparable.

Our results do not support the hypothesis suggested by Cronberg et al. (1988) that the phenomenon of expelling threads of mucilage during cell disintegration, serves as a repellent or even as a toxicant for grazers. It seems to be unlikely that very small amount of mucilage from one cell may affect Daphnia specimen as we did not observe any negative effects on a Daphnia survival in the presence of high concentrations of homogenate biomass. However, such effect cannot be excluded in the case of small zooplankton species. Some earlier reports showed that $G$. semen presence caused cell lysis of Rhodomonas lacustris, probably via expelled mucilage from trichocysts, but this evidence concerned a small $(10 \mu \mathrm{m})$ algal flagellate lacking a cell wall (Rengefors et al., 2008) which may not correspond to the effect on large crustaceans. Nevertheless, recent studies revealed that $G$. semen cells with significantly reduced trichocysts were more vulnerable to grazing by rotifers and copepods, which indicates that these organelles may still play some defensive role in this raphidophyte alga (Björnerås, 2014).

The nutritional value of Gonyostomum as prey for zooplankton was firstly suggested by Williamson et al. (1996). It was revealed that Daphnia reproduction rate was higher when fed on metalimnetic Gonyostomum-rich seston as compared to Gonyostomum-poor epilimnetic seston. Further research indicated that cells of this raphidophyte contain significant amounts of $\omega-3$ polyunsaturated fatty acids (PUFAs), especially eicosapentaenoic and linolenic acid (Gutseit et al., 2007; Johansson et al., 2016), previously found also in marine raphidophytes (Marshall et al., 2002). PUFAs are one of the main (besides phosphorus) limiting 
components in daphnids food (Gulati and Demott, 1997) and play an essential role in the growth of D. magna (Becker and Boersma, 2005; Martin-Creuzburg and von Elert, 2009). Therefore, it became clear that the homogenized Gonyostomum biomass, besides not being harmful, may serves as a nutritive factor supporting body growth of Daphnia, as directly indicated in our experiments. Earlier findings revealed that only large daphinds are able to ingest this raphidophyte cells while smaller species do not due to the large size of the algal cells (Lebret et al., 2012; Johansson et al., 2013); however, a recent study showed that also small-sized rotifers may ingest their cells (680 cells day ${ }^{-1}$ ) and grow on Gonyostomum (Björnerås, 2014). Our findings suggest that daphnids may also benefit from disintegrated $G$. semen biomass, available during or after the algal bloom. Very similar observations were reported for Daphnia feeding on potentially inedible cyanobacteria. Experimental research revealed that decaying biomass of Planktothrix limnetica or Microcystis sp. was more suitable food source for Daphnia spp. than fresh cyanobacterial cells (Repka et al., 1998; Gulati et al., 2001; Luo et al., 2015). A similar mechanism may have occurred in our experiment where frozen and thawed G. semen homogenate from disintegrated cells could be easily ingested and became a satisfactory food source for Daphnia. A decaying G. semen biomass supporting an increase of benthic invertebrate biomass was also suggested by Trigal et al. (2011) but the authors did not present any direct evidence. A more possible explanation could be related to the extended bacterial growth, which may occur on the disintegrated algal biomass, thus creating an additional food source for Daphnia and enhancing its growth. The increase of bacterial abundance at the end of algal blooms is a known phenomenon (Van Boekel et al., 1992). Kamiyama et al. (2000) observed the increase of heterotrophic bacteria numbers around the end of raphidophyte Heterosigma akashiwo bloom as well as the increase in phosphates produced as the bacteria mineralized organic phosphorus originating from decaying algae. Johansson et al. (2016) found that in lakes with higher G. semen biomass, cladoceran species contained more bacterial fatty acids than those of algal origin which revealed that Gonyostomum bloom results in increased utilization of bacterial resources by zooplankton.

Very interesting results were obtained when D. magna was exposed to high densities of live Gonyostomum cells, where we observed a formation of macroscopic mucilaginous algal aggregations. After 24-h exposure, great proportion of crustaceans was entrapped within them, even at not extremely high and environmentally relevant algal biomass $\left(72 \mathrm{~g} \mathrm{FW} \mathrm{m}^{-3}\right)$, and the number of free-swimming Daphnia specimens decreased with increasing algal biomass. Daphnia exposure to the most concentrated biomass $\left(773 \mathrm{~g} \mathrm{FW} \mathrm{m}^{-3}\right)$ resulted in a significant decrease in its survival rate. Thus, it supports our previous observation that highly concentrated biomass homogenates containing cell mucilage might mechanically immobilize daphnids resulting in their higher mortality, probably due to starvation. The formation of algal aggregations in lakes ("lake snow") is known, but rarely documented, due to the fragile nature of this phenomenon (Grossart and Simon, 1993). In experimental studies, aggregations formation was observed in various Scenedesmus species which occurred in the presence of chemicals released by Daphnia to the water (Hessen and Van
Donk, 1993; Luring, 1999). Daphnia-induced increased mucilage production, which resulted in more sticky trichomes in the formation of the large aggregates, was observed in Aphanizomenon flos-aquae (Kiorboe and Hansen, 1993). However, it seems unlikely that Gonyostomum formed aggregations under the influence of zooplankton presence. G. semen aggregation is a known phenomenon that sometimes be seen in lakes during blooms, in dense laboratory cultures or when Gonyostomum net samples are mechanically disturbed during transportation (Koreiviene and Pęczuła, own observations). The mechanism of daphnids immobilization in G. semen aggregations observed in our experiment cannot be excluded as a phenomenon that may exist during mass development of this alga.

The present study enhanced the understanding of the ecology of the expanding flagellate alga $G$. semen, particularly in terms of its interactions with zooplankton grazers. Our results showed, contrary to previous beliefs, that disintegrated $G$. semen biomass is not harmful for crustaceans when it occurs in concentrations even higher than blooms in lakes. The evidence from this study suggests also that disintegrated Gonyostomum cells may serve as nutritive component enhancing daphnids' body growth. However, one of the more interesting findings emerging from this study, is that a dense $G$. semen population forms mucilaginous aggregates which may serve as mechanical traps for daphnids and in this way may enhance organisms mortality. Further, field and experimental investigations are needed to estimate the significance of our findings in the food web of freshwater ecosystems facing mass development of $G$. semen.

\section{References}

Agrawal AA. 1998. Algal defense, grazers, and their interactions in aquatic trophic cascades. Acta Oecol 19: 331-337.

Angeler DG, Johnson RK. 2013. Algal invasions, blooms and biodiversity in lakes: accounting for habitat-specific responses. Harmful Algae 23: 60-69.

Angeler DG, Trigal C, Drakare S, Johnson RK, Goedkoop W. 2010. Identifying resilience mechanisms to recurrent ecosystem perturbations. Oecologia 164: 231-241.

Becker C, Boersma M. 2005. Differential effects of phosphorus and fatty acids on Daphnia growth and reproduction. Limnol Oceanogr 50: 388-397.

Björnerås C. 2014. Grazing resistance due to trichocysts may boost bloom formation in the HAB species Gonyostomum semen. MSc. Thesis, University of Lund, Lund.

Buskey EJ. 1997. Behavioral components of feeding selectivity of the heterotrophic dinoflagellate Protoperidinium pellucidum. Mar Ecol-Prog Ser 153: 77-89.

Clough J, Strom S. 2005. Effects of Heterosigma akashiwo (Raphidophyceae) on protist grazers: laboratory experiments with ciliates and heterotrophic dinoflagellates. Aquat Microb Ecol 39: 121-134.

Cronberg G, Lindmark G, Björk S. 1988. Mass development of the flagellate Gonyostomum semen (Raphidophyta) in Swedish forest lakes - an effect of acidification? Hydrobiologia 161: 217-236.

Figueroa RI., Rengefors K. 2006. Life cycle and sexuality of the freshwater raphidophyte Gonyostomum semen (Raphidophyceae). J Phycol 42: 859-871.

Findlay DL, Paterson MJ, Hendzell LL, Kling HJ. 2005. Factors influencing Gonyostomum semen blooms in a small boreal reservoir lake. Hydrobiologia 533: 243-252. 
Fott B. VIII. Klaasse Chloromonadophyceae. In: Huber-Pestalozzi G, ed. Das Phytoplankton des Süsswassers, Vol. 3, 2nd edn. Stuttgart: Schweizerbart, 1968, pp. 79-93.

Fu M, Koulman A, Van Russel M, et al. 2004. Chemical characterization of three hemolytic compounds from the micro algal species Fibrocapsa japonica (Raphidophyceae). Toxicon 43: 355-363.

Ger KA, Hansson LA, Lürling M. 2014. Understanding cyanobacteria - zooplankton interactions in a more eutrophic world. Freshwater Biol 59: 1783-1798.

Grossart HP, Simon M. 1993. Limnetic macroscopic organic aggregates (lake snow): occurrence, characteristics, and microbial dynamics in Lake Constance. Limnol Oceanogr 38: 532-546.

Gulati R, Demott W. 1997. The role of food quality for zooplankton: remarks on the state-of-the-art, perspectives and priorities. Freshwater Biol 38: 753-768.

Gulati RD, Bronkhorst M, Van Donk E. 2001. Feeding in Daphnia galeata on Oscillatoria limnetica and on detritus derived from it. J Plankton Res 23: 705-718.

Gutseit K, Berglund O, Granéli W. 2007. Essential fatty acids and phosphorus in seston from lakes with contrasting terrestrial dissolved organic carbon content. Freshwater Biol 52: 28-38.

Hagman CHC, Ballot A, Hjermann DØ, Skjelbred B, Brettum P, Ptacnik R. 2015. The occurrence and spread of Gonyostomum semen (Ehr.) Diesing (Raphidophyceae) in Norwegian lakes. Hydrobiologia 744: 1-14.

Hardy J. 2008. Washington State recreational guidance for microcystins (provisional) and anatoxin-a (interim/provisional). Washington: Washington State Department of Health.

Havens KE. 1989. Seasonal succession in the plankton of a naturally acidic, highly humic lake in Northeastern Ohio, USA. J Plankton Res 11: 1321-1327.

Hehmann A, Krienitz L, Koschel R. 2001. Long-term phytoplankton changes in an artificially divided, top-down manipulated humic lake. Hydrobiologia 448: 83-96.

Hessen D, Van Donk E. 1993. Morphological changes in Scenedesmus induced by substances released from Daphnia. Arch Hydrobiol 127: 129-140.

Hillebrand H, Dürselen CD, Kirschtel D, Pollingher U, Zohary T. 1999. Biovolume calculation for pelagic and benthic microalgae. J Phycol 35: 403-422.

Hongve D, Lovstad Ø, Bjorndalen K. 1988. Gonyostomum semen - a new nuisance to bathers in Norwegian lakes. Verh Int Verein Limnol 23: 430-434.

Hutorowicz A, Szeląg-Wasielewska E, Grabowska M, Owsianny P, Pęczuła W, Luścińska M. 2006. Występowanie Gonyostomum semen (Raphidophyceae) w Polsce (The distribution of Gonyostomum semen in Poland). Fragm Florist Geobot Pol 13: 399-409.

ISO 10260. 1992. Water quality - measurement of biochemical parameters - spectrometric determination of the chlorophyll-a concentration. Warsaw: PKN.

ISO 6341.2012. Water quality - determination of the inhibition of the mobility of Daphnia magna Straus (Cladocera, Crustacea) - acute toxicity test.

Johansson KSL, Vrede T, Lebret K, Johnson RK. 2013. Zooplankton Feeding on the Nuisance Flagellate Gonyostomum semen. PLoS ONE 8: 1-6.

Johansson KS, Trigal C, Vrede T, van Rijswijk P, Goedkoop W, Johnson RK. 2016. Algal blooms increase heterotrophy at the base of boreal lake food webs-evidence from fatty acid biomarkers. Limnol Oceanogr 61: 1563-1573.

Kamiyama T, Itakura S, Nagasaki K. 2000. Changes in microbial loop components: effects of a harmful algal bloom formation and its decay. Aquat Microb Ecol 21: 21-30.
Kampe H, König-Rinke M, Petzoldt T, Benndorf J. 2007. Direct effects of Daphnia-grazing, not infochemicals, mediate a shift towards large inedible colonies of the gelatinous green alga Sphaerocystis schroeteri. Limnologica 37: 137-145.

Karosiene J, Kasperovičiene J, Koreiviene J, Vitonyte I. 2014. Assessment of the vulnerability of Lithuanian lakes to expansion of Gonyostomum semen (Raphidophyceae). Limnologica 45: 7-15.

Kiorboe T, Hansen JLS. 1993. Phytoplankton aggregate formation: observations of patterns and mechanisms of cell sticking and the significance of exopolymeric material. J Plankton Res 15: 993-1018.

Lampert W. 1987. Laboratory studies on zooplankton-cyanobacteria interactions. New Zeal J Mar Fresh 21: 483-490.

Le Cohu R, Guitard J, Comoy N, Brabet J. 1989. Gonyostomum semen, a potential nuisance in large French reservoirs? The case of the Pareloup Lake. Arch Hydrobiol 117: 225-236.

Lebret K, Fernández Fernández M, Hagman CH, Rengefors K, Hansson L-A. 2012. Grazing resistance allows bloom formation and may explain invasion success of Gonyostomum semen. Limnol Oceanogr 57: 727-734.

Lepistö L, Antikainen S, Kivinen J. 1994. The occurrence of Gonyostomum semen (Ehr.) Diesing in Finnish lakes. Hydrobiologia 273: 1-8.

Luo X, Liu Z, Gulati R. 2015. Cyanobacterial carbon supports the growth and reproduction of Daphnia: an experimental study. Hydrobiologia 743: 211-220.

Luring M. 1999. Grazer-induced cenobial formation in clonal cultures of Scenedesmus obliquus (Chlorococcales, Chlorophyceae). J Phycol 35: 19-23.

Marshall J-A, Nichols P, Hallegraeff G. 2002. Chemotaxonomic survey of sterols and fatty acids in six marine raphidophyte algae. J Appl Phycol 14: 255-265.

Martel CM, Flynn KJ. 2008. Morphological controls on cannibalism in a planktonic marine phagotroph. Protist 159: 41-51.

Martin-Creuzburg D, von Elert E. 2009. Good food versus bad food: the role of sterols and polyunsaturated fatty acids in determining growth and reproduction of Daphnia magna. Aquat Ecol 43: 943-950.

Mohamed ZA, Al-Shehri AM. 2012. The link between shrimp farm runoff and blooms of toxic Heterosigma akashiwo in Red Sea coastal waters. Oceanologia 54: 287-309.

Negro A, De Hoyos C, Vega J. Phytoplankton structure and dynamics in Lake Sanabria and Valparaíso reservoir (NW Spain). In: Reynolds CS, Dokulil M, Padisák J, eds. The trophic spectrum revisited. Netherlands: Springer, 2000, pp. 25-37.

Okaichi T, ed. 2004. Red tides. Terra Scientific Publishing Company, Tokyo. Dodrecht: Kluwer Academic Publishers.

Pęczuła W. 2013. Habitat factors accompanying the mass appearances of nuisance algal species Gonyostomum semen (Ehr.) Diensig in humic lakes of Eastern Poland. Pol J Ecol 61: 535-543.

Pęczuła W, Poniewozik M, Szczurowska A. 2013. Gonyostomum semen (Ehr.) Diesing bloom formation in nine lakes of Polesie region (Central-Eastern Poland). Ann Limnol - Int J Lim 49: 301308.

Pithart D, Pechar L, Mattsson G. 1997. Summer blooms of raphidophyte Gonyostomum semen and its diurnal vertical migration in a foodplain pool. Algol Stud 85: 119-133.

Pohnert G, Steinke M, Tollrian R. 2007. Chemical cues, defence metabolites and the shaping of pelagic interspecific interactions. Trends Ecol Evol 22: 198-204.

Rengefors K, Pålsson C, Hansson LA, Heiberg L. 2008. Cell lysis of competitors and osmotrophy enhance growth of the bloom forming alga Gonyostomum semen. Aquat Microb Ecol 51: 87-96. 
Rengefors K, Weyhenmeyer GA, Bloch I. 2012. Temperature as a driver for the expansion of the microalga Gonyostomum semen in Swedish lakes. Harmful Algae 18: 65-73.

Repka S, van der Vlies M, Vijverberg J. 1998. Food quality of detritus derived from the filamentous cyanobacterium Oscillatoria limnetica for Daphnia galeata. J Plankton Res 20: 2199-2205.

South GR, Whittick A. 1987. An introduction to phycology. London: Blackwell Science Ltd.

Strom SL, Buskey EJ. 1993. Feeding, growth, and behavior of the thecate heterotrophic dinoflagellate Oblea rotunda. Limnol Oceanogr 38: 965-977.

Tillmann U. 2004. Interactions between planktonic microalgae and protozoan grazers. J Eukaryot Microbiol 51: 156-168.

Tillmann U, Reckermann M. 2002. Dinofagellate grazing on the raphidophyte Fibrocapsa japonica. Aquat Microb Ecol 26: 247-257.

Trigal C, Goedkoop W, Johnson RK. 2011. Changes in phytoplankton, benthic invertebrate and fish assemblages of boreal lakes following invasion by Gonyostomum semen. Freshwater Biol 56: 1937-1948.

Tsuji KI, Watanuki T, Kondo F, et al. 1995. Stability of microcystins from cyanobacteria-II. Effect of UV light on decomposition and isomerization. Toxicon 33: 1619-1631.

Van Boekel WHM, Hansen FC, Riegman R, Bak RPM. 1992. Lysisinduced decline of a Phaeocystis spring bloom and coupling with the microbial foodweb. Mar Ecol-Prog Ser Oldendorf 81: 269-276.
Van Donk E, Luring M, Hessen DO, Lokhorst GM. 1997. Altered cell wall morphology in nutrient-deficient phytoplankton and its impact on grazers. Limnol Oceanogr 42: 357-364.

Vetrova ZI, Okhapkin AG. 1990. Predstaviteli Raphidopyta v vodoemakh Sovetskogo Sojuza (Representatives of Raphidophyta in reservoirs of the Soviet Union). Botanicheskij Zhurnal 5: 631-636.

Vollenweider RA. 1969. A manual on methods for measuring primary production in aquatic environments. Blackwell: Oxford-Edinburgh.

Williamson CE, Sanders RW, Moeller RE, Stutzman PL. 1996. Utilization of subsurface food resources for zooplankton reproduction: Implications for diel vertical migration theory. Limnol Oceanogr 41: 224-233.

Wolfe G. 2000. The chemical defense ecology of marine unicellular plankton: constraints, mechanisms, and impacts. Biol Bull 198: 225-244.

Yan T, Zhou M, Fu M, et al. 2003. The preliminary study on toxicity of Heterosigma akashiwo and the toxicity source. Oceanol Limnol Sin 34: 50-55.

Yoshida T, Hairston NG, Ellner SP. 2004. Evolutionary trade-off between defence against grazing and competitive ability in a simple unicellular alga, Chlorella vulgaris. Proc R Soc London B Biol 271: $1947-1953$.

Cite this article as: Pęczuła W, Toporowska M, Pawlik-Skowrońska B, Koreiviene J. 2017. An experimental study on the influence of the bloom-forming alga Gonyostomum semen (Raphidophyceae) on cladoceran species Daphnia magna. Knowl. Manag. Aquat. Ecosyst., 418,15 . 